\title{
Effect of longitudinal joint on the shear-key of hollow core slab which function as an rigid diaphragm
}

\author{
Gambiro Soeprapto ${ }^{1 *}$, Mukhlis Sunarso ${ }^{1}$, Sumarsono $^{2}$, Ferryandy Murdono $^{1}$, Winda Agustin ${ }^{1}$, Raynelda \\ Siahaan $^{1}$ \\ ${ }^{1}$ PT Wijaya Karya Beton Tbk., Research and Development Departement, 17411 Bekasi, Indonesia \\ ${ }^{2}$ PT Wijaya Karya Beton Tbk., Concrete Product Factory, 16969 Bogor, Indonesia
}

\begin{abstract}
Various types of reinforced concrete floors can be applied to building construction. The floor of the building can be made of cast in place or precast concrete. The floors should function as a rigid diaphragm, in order to distribute the lateral forces on the building frame. While the floor is made of precast concrete, especially those without overtopping, should be arranged in such a way to function as a diaphragm. In order for the precast slab can function as a diaphragm, the components must be connected to the building frame and between the component itself. Some of them are drag strut, boundary element (chord), transverse joint, collector and longitudinal joint. This paper will discuss the influence of the longitudinal joint shear key with some types. The test specimen is modeled as two HCS are mounted parallel to each other, then the both of HCS are combined with perimeter beams to obtain the same model with the actual conditions and simplify to execute. All models of the test specimen are made to represent the three types of shear key. The test specimen is loaded the shear force and observed the structure behavior and crack patterns.
\end{abstract}

\section{Introduction}

Various types of reinforced concrete floors can be applied to building construction. The floor of the building can be made of cast in place concrete or precast concrete. Some types of precast concrete floor including solid slab (full depth slab), half slab, double T slab dan hollow core slab (HCS).

The floors in tall buildings should function as a rigid diaphragm, in order to distribute the lateral forces on the building frame. These properties characters can be obtained, when using a cast in place concrete floor. While the floor is made of precast concrete, especially without overtopping, should be arranged in such a way to function as a diaphragm.

Hollow Core Slab (HCS) is a type of plate precast components that behave in one direction (one way slab). The width range of HCS between $80-120 \mathrm{~cm}$, while the length varies with the size of the longest can up to 20 meters.

Because one way slab, so the HCS are supported by two beams at the both ends. The beams are part of the building structure. The other two sides are not connected to the parallel beam.

In order for the precast slab can function as a diaphragm, then the components must be connected to building frame associated with the building frame and between the component itself. Some of them named drag strut, boundary element (chord), transverse joint, collector and longitudinal joint.

Longitudinal joint shear key form can be filled with materials or other components. There are three types of shear key that mortar, longitudinal reinforcement and shear reinforcement are mounted transversely.

\section{Theory and design}

Hollow core slabs are used as floor or roof to support vertical loads. But besides that also functions as a diaphragm to restrain and distribute lateral loads Lateral load be caused lateral pressure, wind loads or seismic loads. The main problem in planning the hollow core connection diaphragm is design to distribute the load to the diaphragm, the strength and ductility of slab system to carry the loads to the lateral load-bearing element. 


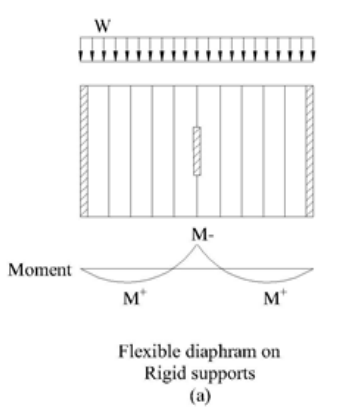

Fig. 1. Diagram bending moments.

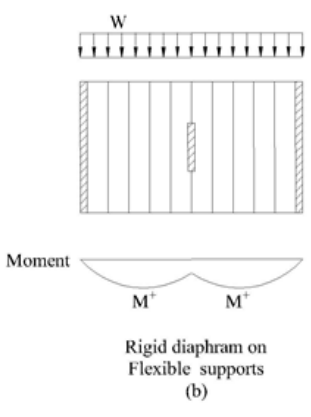

\subsection{Diaphragm element}

- Boundary element : edge element around the diaphragm or perimeter of the diaphragm opening and together that bind together. Boundary element described as the pull rod / push (chord) or slider (drag strut).

- Collector : element that distribute the shear force of the diaphragm to the lateral retaining elements.

- Chord : Pull or push elements as a result of the behavior of the wing on the diaphragm to produce bending in the integrity of the diaphragm.

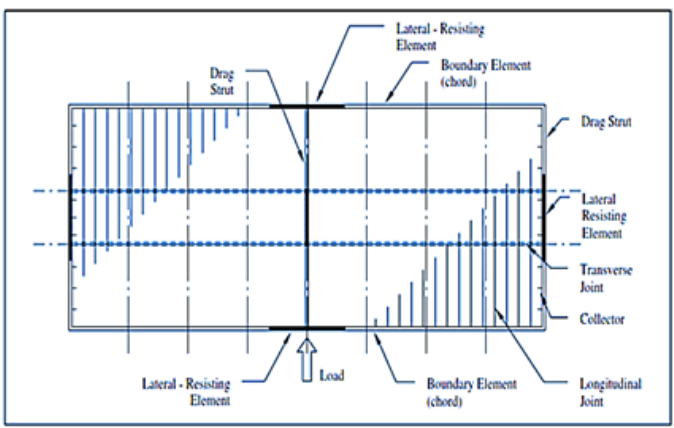

Fig. 2. Diaphragm elements.

The diaphragm must have the strength to distribute lateral loads imposed on the point to the point of lateral load resisting. Spans of the diaphragm between the lateral anchoring element behaves as a high beam and tied arch.

\subsection{Longitudinal connection}

Shear keyway are grouted between the slab has the capacity to distribute the longitudinal shear forces from one slab to the next slab. With shear stress $0.55 \mathrm{MPa}$, the nominal shear forces is

$$
\begin{aligned}
\phi V_{n}=\phi(0.55) & h_{n} I \\
I & =\text { length of connection }(\mathrm{mm}) \\
h_{n} & =\text { depth of grouted keyway. }(\mathrm{mm}) \\
\phi & =0.85
\end{aligned}
$$

If the grout strength is exceeded or ductile behavior is required, in principle, the sliding friction can be used to plan reinforcement is placed perpendicular to the longitudinal joint. This reinforcement can be placed on a transverse joint at the end of the slab rather than distributed throughout the connection.

$$
A_{v f}=\frac{V_{u}}{\emptyset f_{y} \mu}
$$

$V_{u}=$ factored ultimate shear force

$\mu=1.0$ for shear strength which parallel to longitudinal connection.

$\begin{aligned}= & \begin{array}{l}1.4 \text { for shear strength which } \\ \text { parallel } \\ \text { connection. }\end{array} \\ \phi= & 0.85\end{aligned}$

\section{Modelling and set up sample of testing}

\subsection{Modelling of sample}

Shear testing the keyway Hollow Core Slab (HCS) is modeled with a 2-pieces HCS sheet is fastened with boundary elements. This boundary element serves to unite two pieces of HCS, to be given the test load. Besides this modeling represent actual conditions attached HCS.

Deformation shows the performance of the connection system to be applied

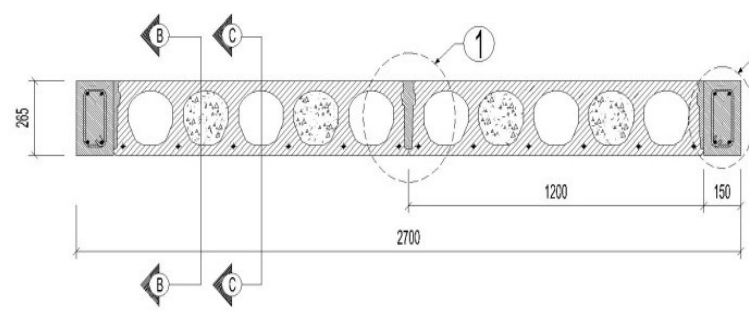

Fig. 3. Section of hollow core slab.

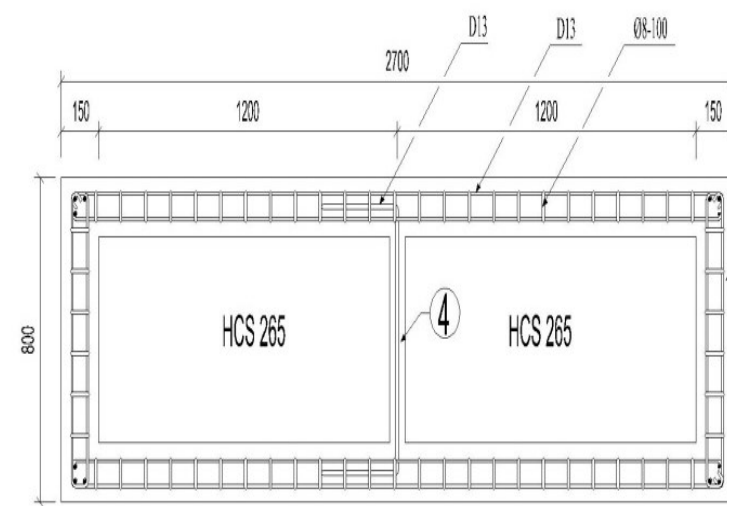

Fig. 4. Model of specimen. 


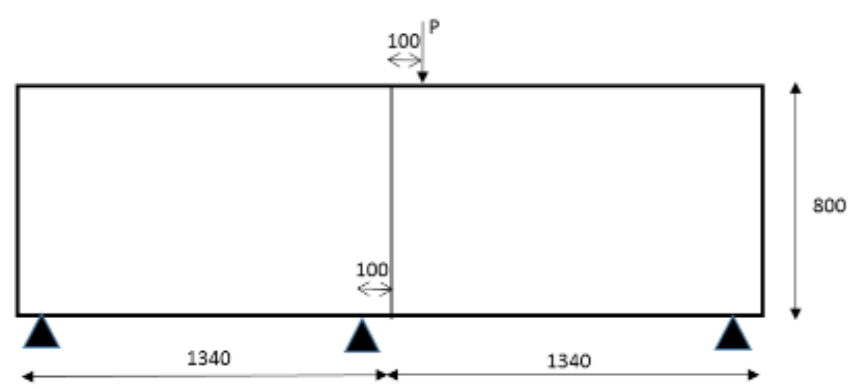

Fig. 5. Load pattern.

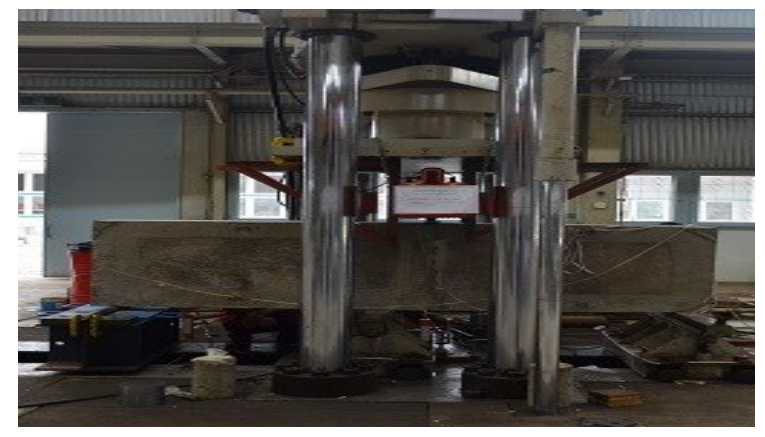

Fig. 6. Set up of specimen.

\subsection{Sample of testing}

Sample consist of 4 types :

\section{- Specimen type 1 (BU-1)}

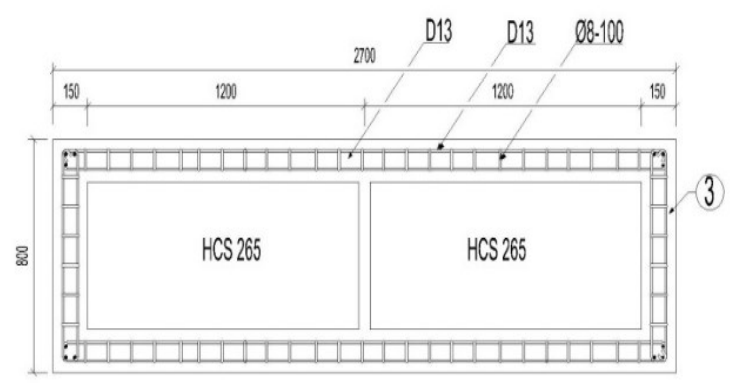

Fig. 7. Steel reinforcement for specimen type 1

No reinforment at shear keyways. Only rely on the specimen and concrete filler This specimen has function as comparison.

\section{- $\quad$ Specimen type 2 (BU-2)}

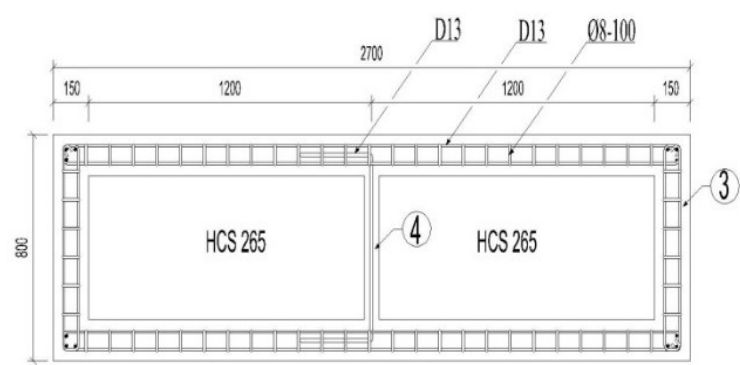

Fig. 8. Steel reinforcement for specimen type 2
Reinforcement in the shear keyway in the form of longitudinal reinforcement along the channel. It consist of $1 \mathrm{D} 13$ steel reinforcement.

- $\quad$ Specimen type 3 (BU-3)

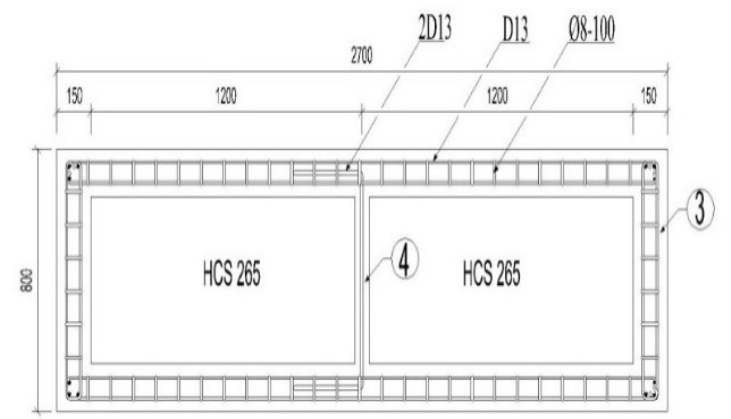

Fig. 9. Steel reinforcement for specimen type 3

Reinforcement in the shear keyway in the form of longitudinal reinforcement along the channel. It consist of 2D13 steel reinforcement.

- Specimen type 4 (BU-4)

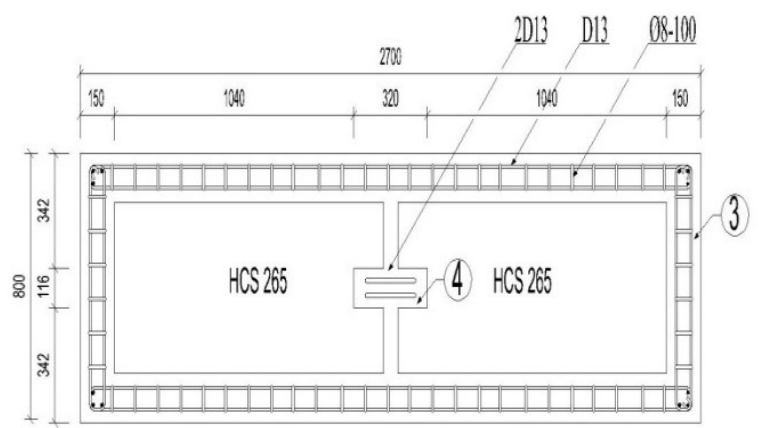

Fig. 10. Steel reinforcement for specimen type 4 .

Reinforcement in the shear keyway in the form of transversal reinforcement at the middle of channel. It consist of 2D13 steel reinforcement.

- Specimen type 5 (BU-5)

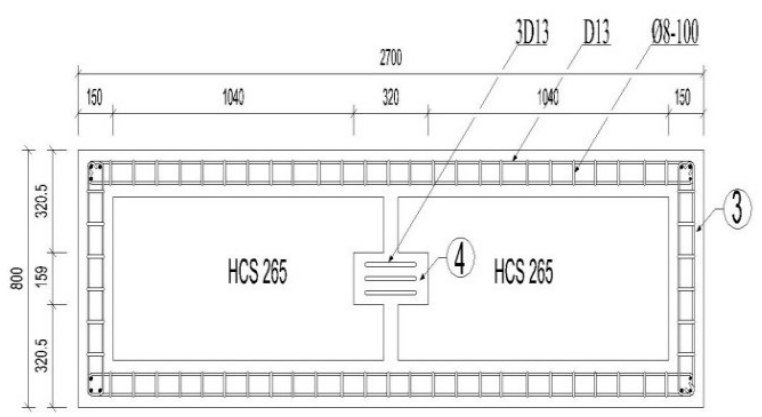

Fig. 11. Steel reinforcement for specimen type 5.

Reinforcement in the shear keyway in the form of transversal reinforcement at the middle of channel. It consist of 3D13 steel reinforcement. 


\section{Discussion and analysis}

The test load $\mathrm{F}$ acts on the test object as figure 3D. But the style is observed is the force exerted on the joints between panels HCS Therefore, these forces should be determined by structural analysis. Oleh karena itu gayagaya tersebut harus ditentukan dengan analisa struktur. Structure of HCS is modeled as two shell elements are tied with boundary elements, so that a single unitary structure. Structural analysis is done by SAP2000.

\subsection{Specimen 1}

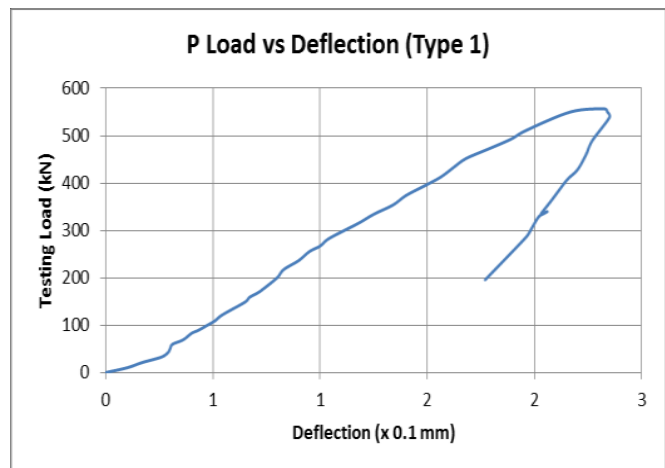

Fig. 12. Graph of $P$ vs deflection (Type 1)

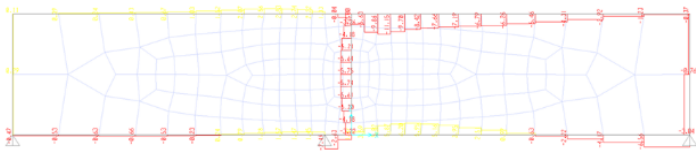

Fig. 13. Stress contour (Type 1)

BU-1 has no reinforement. Testing load is 574.87 $\mathrm{kN}$. From structural analysis, the axial force is $56.41 \mathrm{kN}$ at shear key.

Shear strength of longitudinal connection without reinforcement can be calculated with equation (1).

$$
\begin{aligned}
\phi V_{n} & =\phi(0.55) h_{n} \ell \\
& =0.85 \times 0.55 \times 265 \times \\
& =37166.25 \mathrm{~N} \\
& =\quad 37.166 \mathrm{kN}
\end{aligned}
$$

The forces as testing result is $56.41 \mathrm{kN}>37.17 \mathrm{kN}$. These results indicate that the shear key without reinforcement and using only rely bond between shear key and concrete fillers give good results.

The magnitude of the deflection is small indicates that the structure is not deformed significantly

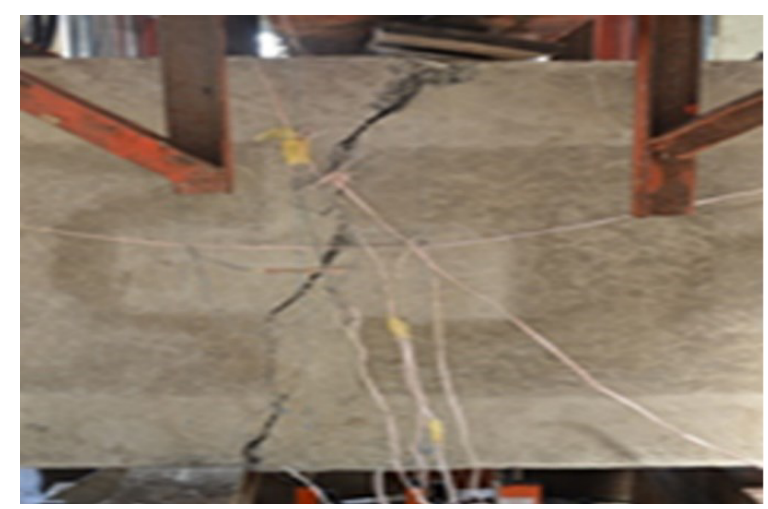

Fig. 14. Crack pattern for Specimen Type 1

Collapse pattern is almost similar to the collapse pattern as results of the finite element analysis. Stress flow that occurs as predicted, from stress due to the $\mathrm{P}$ load flows into the support. But the damage occurs earlier in the body slightly below the boundary elements, causing the upper boundary elements are also damaged first. As a result of the test load will stop, but the structure did not undergo plastic condition. So the ductility is small.

Deflection at maximum load is $2.04 \mathrm{~mm}\left(\Delta_{y}\right)$. While the maximum deflection is $2.71 \mathrm{~mm}\left(\Delta_{u}\right)$ at load 543.57 $\mathrm{kN}$. So, the ductility is $\Delta_{u} / \Delta_{u}=2.71 / 2.04=1.33$.

\subsection{Specimen 2}

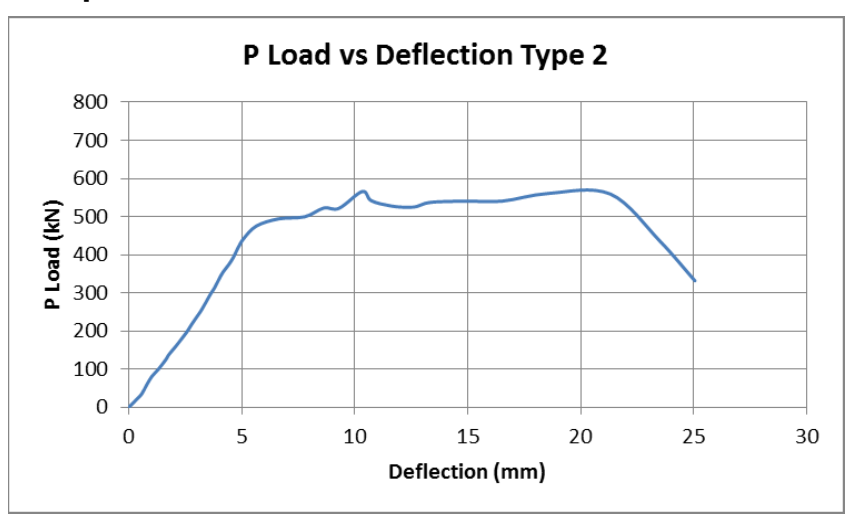

Fig. 15. Graph of $P$ vs deflection (Type 2).

BU-2 has 1D13 reinforcement at shear key. Testing load for BU-2 is $601.45 \mathrm{kN}$. The analysis result is 57.58 $\mathrm{kN}$.

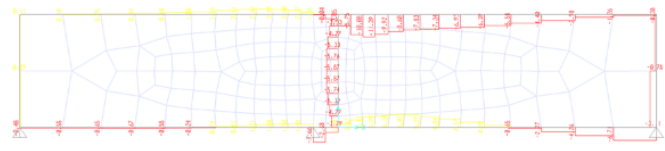

Fig. 16. Stress contour (Type 2)

Deflection at maximum load is $7.79 \mathrm{~mm}\left(\Delta_{y}\right)$. While the maximum deflection is $20.99 \mathrm{~mm}\left(\Delta_{u}\right)$ at load $431.74 \mathrm{kN}$. So, the ductility is $\Delta_{u} / \Delta_{u}=20.99 / 7.79=2.69$. 


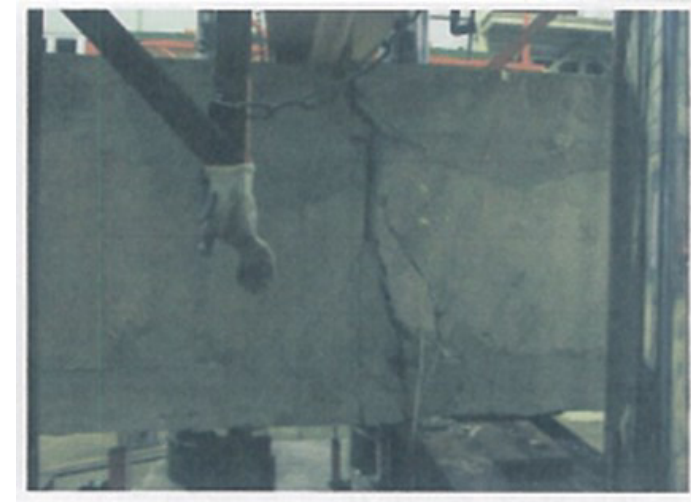

Fig. 17.. Crack pattern for Specimen Type 2.

Shear strength of longitudinal connection with reinforcement can be calculated with equation (2).

$$
\begin{array}{rrrrrrrr}
A_{v f} & = & 1 \mathrm{D} & 13 & & & \\
& = & 132.73 \mathrm{~mm}^{2} & & & & & \\
& & & & & & & \\
V_{u} & = & 132.73 \times & \times & 0.85 & \times & 400 \times & 1.0 \\
& = & 45128.98 \mathrm{~N} & & & & & \\
& = & 45.13 \mathrm{kN} & & & & &
\end{array}
$$

Damage from the loading point to the pivot formed a diagonal flow incomplete. When cracks diagonal touch shear connection, it cracks into line with the connection. Damage caused quite severe, because this connection is the weakest part.

\subsection{Specimen 3}

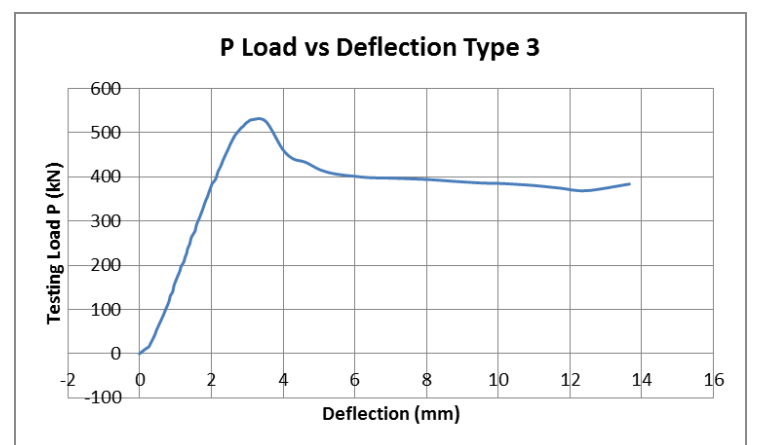

Fig. 18. Graph of $P$ vs deflection (Type 3).

BU-3 has 1D13 reinforcement at shear key. Testing load for BU-2 is $521.6 \mathrm{kN}$. The analysis result is 49.93 $\mathrm{kN}$.

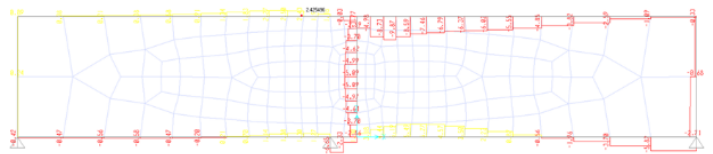

Fig. 19. Stress contour (Type 3)

Deflection at maximum load is $3.565 \mathrm{~mm}\left(\Delta_{y}\right)$. While the maximum deflection is $15.14 \mathrm{~mm}\left(\Delta_{u}\right)$ at load 427.23 $\mathrm{kN}$. So, the ductility is $\Delta_{u} / \Delta_{u}=15.14 / 3.565=4.25$.

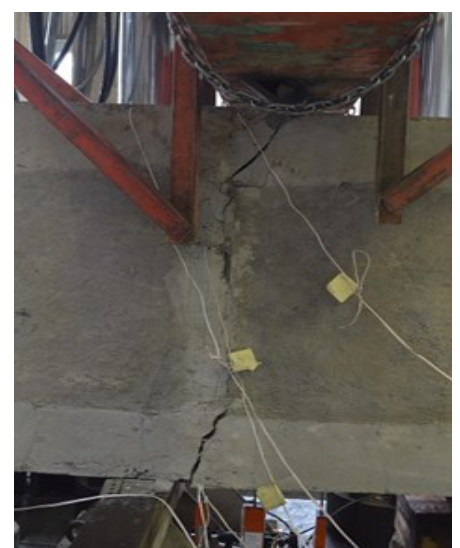

Fig. 20. . Crack pattern for Specimen Type 3.

Shear strength of longitudinal connection with reinforcement can be calculated with equation (2).

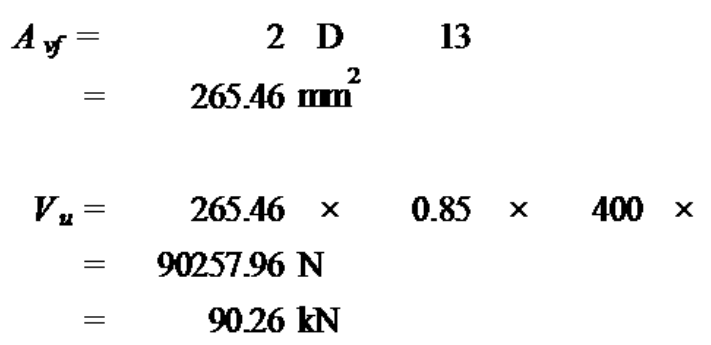

Damage from the loading point to the pivot formed a diagonal flow incomplete. When cracks diagonal touch shear connection, the cracks being along the connection. This is due to the shear connection is the weakest part. The addition of longitudinal shear reinforcement can improve ductility.

\subsection{Specimen 4}

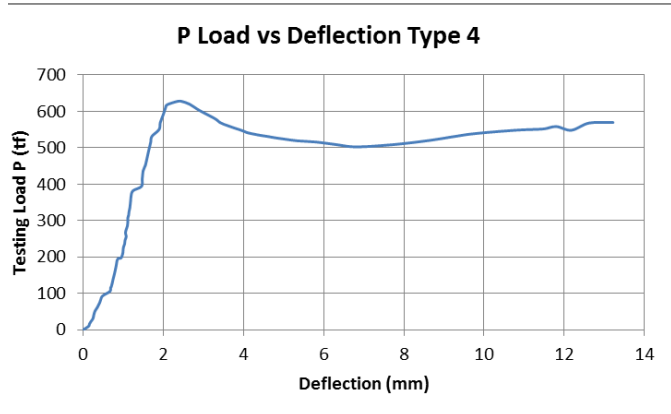

Fig. 21. Graph of P vs deflection (Type 4).

BU-4 has 2D13 reinforcement perpendicular at shear key. Testing load for BU-2 is $656.04 \mathrm{kN}$. The analysis result is $62.78 \mathrm{kN}$

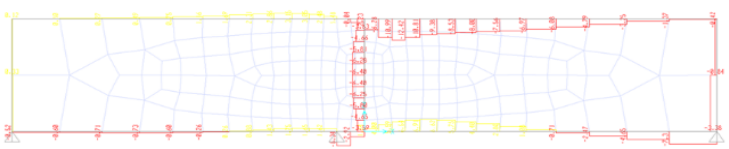

Fig. 22. Stress contour (Type 4)

Deflection at maximum load is $3.565 \mathrm{~mm}\left(\Delta_{y}\right)$. While the maximum deflection is $15.14 \mathrm{~mm}\left(\Delta_{u}\right)$ at load 427.23 $\mathrm{kN}$. The ductility is $\Delta_{u} / \Delta_{u}=13.22 / 2.14=6.18$. 


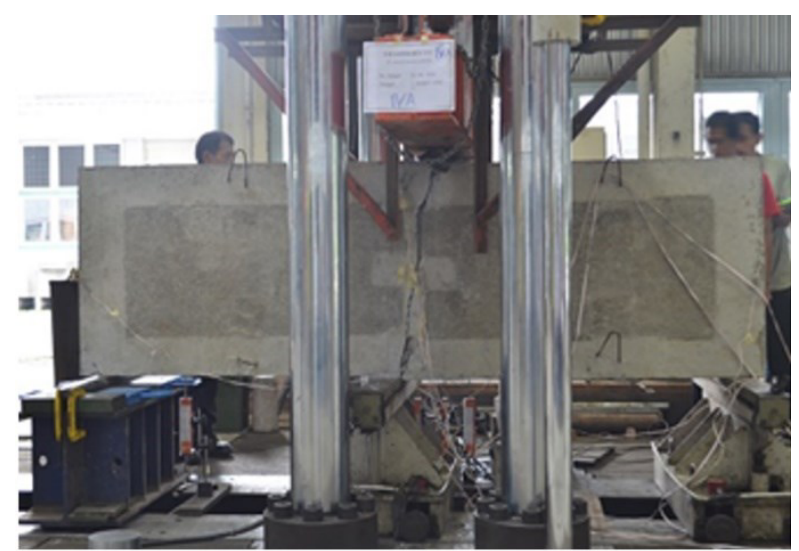

Fig. 23. Crack pattern for Specimen Type 4

Shear strength of longitudinal connection with reinforcement can be calculated with equation (2).

$$
\begin{aligned}
& A_{v f}=\quad 2 \quad \mathrm{D} \quad 13 \\
& =\quad 265.46 \mathrm{~mm}^{2}
\end{aligned}
$$

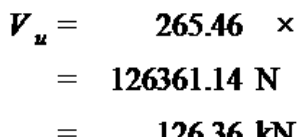

Damage from the loading point to the pivot formed a diagonal flow as prediction. The addition of longitudinal shear reinforcement can improve ductility.

\subsection{Specimen 5}

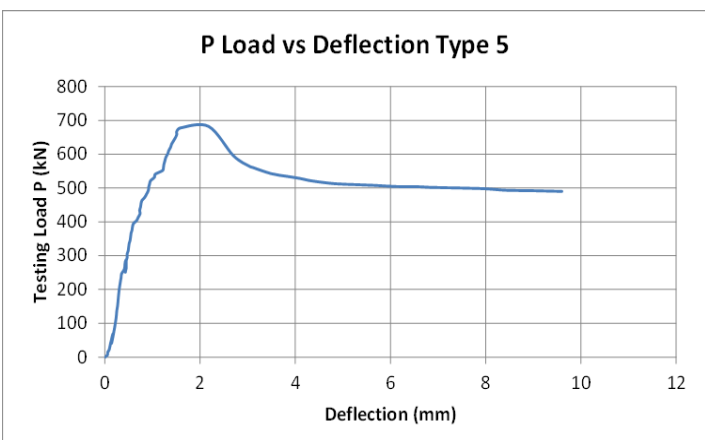

Fig. 24. Graph of $P$ vs deflection (Type 5).

BU-5 has 3D13 reinforcement perpendicular at shear key. Testing load for BU-2 is $682.38 \mathrm{kN}$. The analysis result is $65.33 \mathrm{kN}$.

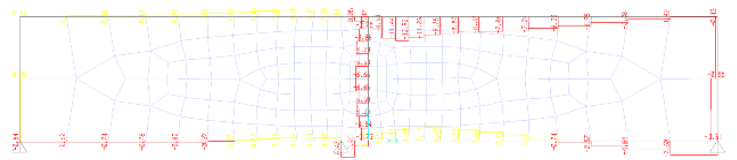

Fig. 25. Stress contour (Type 5)
Deflection at maximum load is $2.18 \mathrm{~mm}\left(\Delta_{y}\right)$. While the maximum deflection is $9.6 \mathrm{~mm}\left(\Delta_{u}\right)$ at load $490.30 \mathrm{kN}$. So, the ductility is $\Delta_{u} / \Delta_{u}=9.6 / 2.18=4.40$.

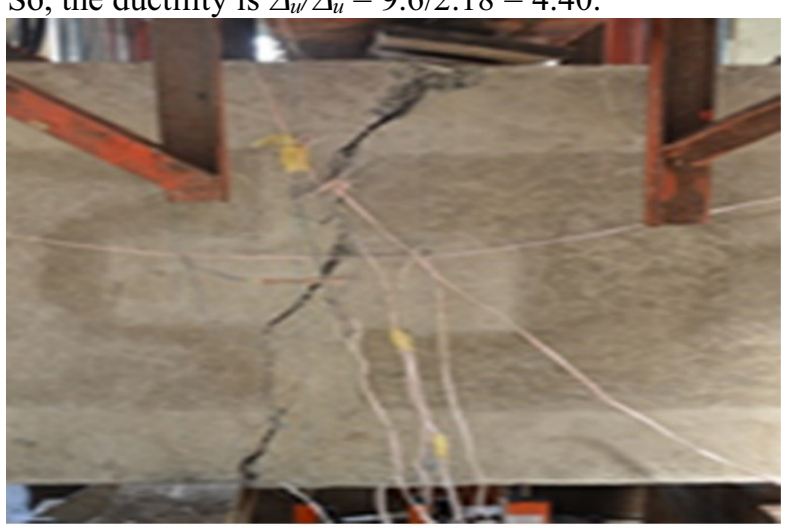

Fig. 26. Crack pattern for Specimen Type 5

Shear strength of longitudinal connection with reinforcement can be calculated with equation (2).

$$
\begin{aligned}
& A_{v f}=\quad 3 \quad \mathrm{D} \quad 13 \\
& =\quad 398.20 \mathrm{~mm}^{2} \\
& V_{u}=\quad 398.20 \times 0.85 \times 400 \times \\
& =189541.71 \mathrm{~N} \\
& =\quad 189.54 \mathrm{kN}
\end{aligned}
$$

The pattern of damage is similar to BU-4

Table 1. Test Result

\begin{tabular}{|c|c|c|c|}
\hline $\begin{array}{c}\text { Sample } \\
\text { No. }\end{array}$ & $\boldsymbol{V}_{\boldsymbol{u}}(\boldsymbol{k N})$ & $\boldsymbol{V}_{\text {geser }}(\boldsymbol{k N})$ & Ductility $(\boldsymbol{\Delta u} / \Delta \boldsymbol{y})$ \\
\hline 1 & 37.17 & 55.41 & 1.33 \\
\hline 2 & 45.13 & 44.01 & 2.69 \\
\hline 3 & 90.26 & 49.93 & 4.25 \\
\hline 4 & 126.36 & 62.78 & 6.18 \\
\hline 5 & 189.54 & 65.33 & 4.40 \\
\hline
\end{tabular}

\section{Conclusion}

1. Installation and additional longitudinal reinforcement (BU-2 and BU-3) on the shear key does not give the shear strength significantly, but to improve its performance in terms of ductility.

2. Transverse reinforcement BU-4 dan BU-5 in this study does not give a significant increase compared to BU-2 and BU-3, but get a good ductility. The increase is not significant be caused the number of possibilities that only one set of reinforcement. Besides the possibility of anchoring insufficient, can affect the shear strength.

3. Longitudinal shear key between HCS with 2 or more longitudinal reinforcement likes type 3 can be used for HCS diaphragm. This reinforcement must be anchored to the supporting beam. One advantage of this system is the ease of implementation. 


\section{References}

1. PCI Hollow Core Slabs Producers Committee, PCI Manual for The Design of Hollow Core Slabs, Second Edition, 4-1 - 4-9 (1998)

2. G. Soeprapto, Laporan Penelitian Geser Hollow Core Slab, (2016)

3. Puslitbang Permukiman Kemen. PUPERA, Pengujian Geser Hollow Core Slab, 1, (2015)

4. Puslitbang Permukiman Kemen. PUPERA, Pengujian Geser Hollow Core Slab, 2, (2016)

5. M. Menegotto, G. Monti, Diaphragm Action of Precast Floors : Behavior and Modelling, (1996)

6. MD Herlihy, R. Park, Precast Concrete Floor Support and Diaphragm Action,(1996)

7. R. Fenwick, D. Bull, D. Gardiner, Assesment of hollow-core floors for Seismic performance, (2010)

8. S. Dow Nakaki, G.R. Stevens, J.R. Harris, Precast Concrete Design. 